\title{
The Effect of Interactive Multimedia Based Learning Model with 4C Integrated and HOTS on Learning Results Instructional System Design (ISD)
}

\author{
R. Mursid ${ }^{1}$, Abdul Hasan Saragih ${ }^{2}$, Naeklan Simbolon ${ }^{3}$ \\ \{ mursid.tp@gmail.com ${ }^{1}$, ahasansaragih@gmail.com²,naeklan.simbolon@yahoo.com ${ }^{3}$ \} \\ Education Technology, Universitas Negeri Medan, Medan, Indonesia ${ }^{1,2,3}$
}

\begin{abstract}
This research aims to determine: (1) the effect of learning model based on interactive multimedia with integrated 4C towards ISD learning outcomes; (2) the effect of structured and unstructured HOTS abilities towards ISD learning outcomes; and (3) interaction between 4C-based learning models and HOTS abilities towards ISD learning outcomes. The research method using quasi-experimental with a $2 \times 2$ factorial design. The statistical test using descriptive statistics to present data and continued with inferential statistics using two-way ANOVA. The results of research obtained showed: (1) the ISD learning outcomes are taught using bay learning model based on interactive multimedia with integrated $4 \mathrm{C}$ was higher than the learning outcomes taught with a learning model not integrated with 4C; (2) the ISD learning outcomes that have structured HOTS abilities was higher than unstructured HOTS abilities; and (3) there was an interaction between model based on interactive multimedia with integrated $4 \mathrm{C}$ and HOTS abilities towards ISD learning outcomes.
\end{abstract}

Keywords: learning models, interactive multimedia, 4C integration, HOTS, instructional system design.

\section{Introduction}

Instructional system design learning (ISD) in the 21st century has objectives with $4 \mathrm{C}$ characteristics, namely; Communication, Collaboration, Critical Thinking and Problem Solving, Creativity and Innovation. The ability to thinking an ability to process mental operations which include perception and creation knowledge. An ability to thinking an ability to use the mind to find meaning and understanding of something to explore ideas, take decisions, think of solutions with the best consideration and revise the problems in the previous thinking process.

Low ISD learning outcomes for students in postgraduate programs, because;(1) the ability to think high-level or through the stages of 4C and HOTS was rarely done in organizing and constructing learning and developing learning by using models that are suitable for students;(2) lack of in-depth understanding of the concept and implementation of ISD in classroom learning applications; and (3) the use of interactive multimedia-based learning to make it easier to absorb knowledge on the basis of construction against ISD. The tendency of change and innovation in the world of education will continue to occur and develop in the 21st century. According to Saud (2011) that innovation in the field of education was attempt to make changes with the aim of getting good things in the field of 
education. These changes include: easier to find learning resources, more choices to use and utilize ICT, the increasing role of media and multimedia in learning activities, more flexible learning time, computer-based instruction (CBI), computer assisted instruction (CAI), the use of television / video media, mobile learning, e- learning, learning management systems, on-line curriculum, e-library, learning models with individual learning systems, competence references. Some education researchers state that technology has the potential to improve the quality of learning. (Liao, 1992). The use of media creatively can facilitate and improve learning efficiency so that learning objectives can be achieved. Learning media, one of the important aspects in the education process, according to Schramm in Sudrajat (2008) learning media was a messenger technology that can be used for learning purposes. In addition, the media has various benefits including helping teachers to deliver their teaching material, the media also seen as a communication tool that bridges abstract ideas with the real world. The use of media also makes the process of interaction, communication and deliveryof material between lecturers and students so that it can take place appropriately and efficiently. Along with the development of technology, nowadays there are various kinds of learning media, one of the media that has many advantages from other media, namely computer multimedia because every information in the form of writing, audio, and images can be shown simultaneously. Some studies show that the use of interactive multimedia can improve mastery of concepts (Ferawati, 2011), learning achievement (Prastika, et al, 2015), and critical thinking skills (Wiyono, et al, 2009).

Arsyad (2011) argues that interactive media was a delivery media system that presents video recording material with computer control to the audience who not only hear and see video and sound, but also provide an active response and response that determines the speed and presentation sequence. Interactive media has an audio-visual element and called interactive because the media was designed to actively involve the user response. The definition of multimedia varies depending on the scope of the application and the development of multimedia technology itself. Multimedia not only has the meaning between simple text and graphics, but also comes with sound, animation, video, and interaction. While listening to explanations can see pictures, animation or read explanations in the form of text (Sutopo, 2008). Multimedia combines text, art, sound, images, animation, and videos delivered with a computer and can be delivered interactively. Suyanto (2003) describes multimedia as the use of computers to create and combine text, graphics, audio, moving images (video and animation) by combining links and tools that allow users to navigate, interact, create and communicate. According to Vaughan (2011), there are three types of multimedia, namely interactive multimedia, hyperactive multimedia, linear multimedia, and multimedia. Meanwhile, according to Sigit (2008), multimedia was divided into two categories, namely: linear multimedia and interactive multimedia. Interactive Multimedia tool that was equipped with a control device that can be operated by its users in choosing something they want. Examples of interactive multimedia are: interactive multimedia learning, game applications and others. The preparation of the learning model was done by paying attention to the components as proposed by Seels and Richey (1994), namely: Design, development, utilization, management, and evaluation. The development of interactive multimedia-based learning models as stated contains the principles of learning, namely: (1) learning and knowledge are in the diversity of opinions; (2) Learning a process of connecting information sources, especially special nodes; (3) Learning can occur from something outside of humans; (4) the ability to understanding more important than understanding now; (5) maintaining continuity in learning was very necessary for the continuation of learning; (6) the ability to see the relationship between ideas and concepts 
as a core skill in learning; (7) updates (accuracy and up-to-date knowledge) are the main things in learning; and (8) decision making in choosing what to learn was very important in the learning process in dealing with a large amount of information. ISD learning was held in the hope that students are able to capture/receive, process, store, and release information that has been processed. Media that can accommodate these requirements a computer. Computers are able to present information that can take the form of video, audio, text, graphics, and animation. For example, in ISD learning, some topics that are difficult to convey conventionally or require high application, can be implemented with the help of computer / multimedia technology, such as graphics and diagrams can be presented easily and quickly, the appearance of images, colors, visualization, video, Animation can optimize the role of the senses in receiving information into the information system (Kariadinata, 2010). Based on this explanation, it can be concluded that multimedia-based learning was learning that uses computer/multimedia assistance using Android.

There are several presentation formats of Interactive multimedia based learning according to Nandi (2006) as follows: (1) the tutorial modeling one of the interactive learn of models used in the teaching and learning process using software in the form of computer programs containing course material; (2) the Drills model was a form of computer-based interactive learning model; (3) the simulation model was basically one of the learning strategies that aims to provide real experience through the creation of imitations of experiences that approach the real atmosphere and take place in an atmosphere without risk; and (4) the instructional games model was one of the learning models using computer-based interactive multimedia. Based on research conducted by Ferawati (2011), Interactive multimedia learning models can improve mastery of the concepts of physics teachers. In addition, it was also supported the results by Sriyanti (2012) research that utilizes multimedia in learning blended elearning models as well as student learning outcomes. Other research also shows that the development of interactive multimedia learning can improve the mastery of student concepts (Gunawan, et al, 2014). From both studies, it was clear that interactive multimedia learning provides benefits to learning. In interactive multimedia learning, students can learn certain material independently by using computers equipped with multimedia-based programs (Kadir and Triwahyuni, 2003).

The role of education in universities was contained in the IQF-based curriculum, focusing on developing students in learning outcomes such as cognitive, affective and psychomotor, or spiritual attitudes, social attitudes, knowledge and skills. Higher order thinking skills are one indication of the success of improving the competence of students in the education sector in the 21 st century. Two very simple reasons that make why HOTS was important, that students will succeed (achieve) and grow into adults who make positive contributions to society (Conklin, 2012). There are several characteristics of HOTS according to Conklin (2012), namely "characteristics of higher-order thinking skills: higher-order thinking skills encompass both critical thinking and creative thinking." The purpose of the passage was the characteristic of high-level thinking abilities including critical thinking and creative thinking. Critical and creative thinking are two very basic human abilities because critical thinking and creative thinking can encourage someone to always look at every problem faced critically, and try to find a solution creatively, so that a new thing was better and useful for their life.

Resnick (1987) said, HOTS has characteristics, as expressed that was non-algorithmic, complex, multiple solutions, involves a variety of decision making and interpretation, application of multiple criteria, and effortful (requires a lot of business). It was called effortful because when it comes to solving HOTS, it requires more and deeper thinking. 
Critical Thinking was a mental process for analyzing information obtained. This information was obtained through observation, experience, communication, or reading. In addition, Brookhart (2010) mentions that including critical thinking includes covering reasoning, questioning and investigating, observing and describing, comparing and connecting, find complexity, and explore perspectives. Critical thinking was an organized process that allows students to evaluate evidence, assumptions, logic, and language that underlies the thinking of others (Johnson, 2013). The ability to think creatively includes creating, discovering, imagining, guessing, designing, proposing alternatives, creating and producing something (Thomas, 2010). Forming creative ideas means coming up with something unusual, new, or creating solutions to a problem. A person's ability to think creatively can be demonstrated through several in dicators, for example being able to propose new ideas, ask questions, dare to experiment and plan strategies.

The research problem: (1) The ISD learning outcomes in education for students taught using integrated interactive multimedia learning models $4 \mathrm{C}$ and HOTS (MPMI4C-HOTS) higher than those taught using expository learning models with HOTS; (2) The ISD learning outcomes in the education of students who have high critical thinking skills higher than students who have low critical thinking skills; and (3) Are there interactions between learning models and the ability to think critically affect student learning outcomes of ISD?

\section{Methods}

This research was conducted in the Education Technology postgraduate program, in the ISD course in Education. The population of this study were all students who took ISD subjects, which consisted of 3 classes, and with cluster random sampling technique. This research using Quasi Experiment $2 \times 2$ factorial design. The learning model was divided into two, namely the MPMI4C-HOTS learning model and the expository learning model with HOTS. Critical thinking skills are also divided into two, namely high critical thinking skills and low critical thinking skills.

Data collection techniques use ability tests on ISD mastery on aspects of Dick \& Carey learning system design with ten instructional stages based on learning outcomes according to the IQF in the Educational Technology learning program. The second using the instrument of knowing students' critical thinking abilities. This analysis was carried out using 2 x 2 factorial Anova technique with F test. Before the hypothesis was tested, the requirements for the collected data were tested by using the normality test using the Liliefors test and homogeneity test using the F test and Bartlett test. Because the third hypothesis was significant, meaning there an interaction, then the research test was continued using the Scheffe test

\section{Results And Discussion}

Based on the results of the normality test the data shows that all groups of subjects are normally distributed, thus it can be concluded that the research sample comes from a population that was normally distributed and thus the subject group taught with MPMI4CHOTS learning model and taught by HOTS expository learning model based on high and low critical thinking abilities have homogeneous variance. After testing the requirements of 
the analysis, it was necessary to have the results that all data in the subject group are normally distributed and have a homogeneous variance, thus the requirements related to the twoway variance analysis technique have been met.

ISD learning outcomes of students taught with MPMI4C-HOTS learning model are higher than students taught with HOTS expository learning model. From the results of calculations with Anova in table 1 it was obtained that Fcount $=6.15$ and Ftable $=4.07$ at a significance level of 0.05. This means that Fcount $>$ Ftable shows that the null hypothesis (Ho) rejected and the alternative hypothesis (Ha) was accepted. Thus, it can be stated that ISD learning outcomes of students taught by MPMI4C-HOTS learning model are higher than ISD learning outcomes of students taught by HOTS expository learning model.

Table 1: The Calculation Results of ANOVA

\begin{tabular}{lcccccc}
\hline $\begin{array}{l}\text { Source of } \\
\text { Variance }\end{array}$ & $\mathrm{dk}$ & $\begin{array}{c}\text { Num ber of } \\
\text { Squar es }\end{array}$ & $\begin{array}{c}\text { Average } \\
\text { Number of } \\
\text { Squares }\end{array}$ & $\mathrm{F}_{\text {count }}$ & $\begin{array}{c}\text { F Fable } \\
\alpha=0,05\end{array}$ \\
\hline $\begin{array}{l}\text { Learning Model } \\
\text { (A)/column }\end{array}$ & 1 & 28.69 & 27.69 & 6.15 & 4.07 \\
$\quad \begin{array}{l}\text { Critical } \\
\text { Thinking }\end{array}$ & 1 & 87.07 & 86.07 & 19.13 & 4.07 \\
$\begin{array}{l}\text { Ability (B)/line } \\
\text { Interaction (A x }\end{array}$ & 1 & 59.11 & 58.11 & 12.9 & 4.07 \\
$\begin{array}{l}\text { B) Error } \\
\text { Total }\end{array}$ & 43 & 194.45 & 4.499 & 2 & - & - \\
\hline
\end{tabular}

ISD learning outcomes students who have high critical thinking skills are higher than students who have low critical thinking skills. Based on the results of calculations with Anova in table 1 it was obtained the results of the ISD student learning outcomes data calculation based on critical thinking abilities, namely Fcount $=19.13$ and Ftable $=4.07$ at a significance level of 0.05 . This means that Fcount $>$ Ftable, shows that the null hypothesis (Ho) was rejected and the alternative hypothesis (Ha) was accepted. This it can be stated that ISD learning outcomes of students who have high critical thinking skills are higher than those with low critical thinking skills.

Interaction between learning models and the ability to think critically about ISD learning outcomes. In this case, the ability to think critically was divided into two categories, namely low and high. From the results of calculations with the Anova table in table 1 it was obtained that Fcount $=12.92$ and Ftable $=4.07$ at a significant level of 0.05. This means that Fcount $>$ Ftable, shows that the null hypothesis (Ho) was rejected and the alternative hypothesis (Ha) was accepted. This it can be stated that there was an interaction between learning models and the ability to think critically about student learning outcomes of ISD.

Based on some of the most important research findings in the form of ISD learning principles shows that: (1) the learning model of MPMI4C- HOTS can improve student learning competencies in the cognitive, affective, and psychomotor domains, (2) through software skills students can improve the ability to collaborate in groups learning, able to apply various abilities skillfully when working on structured tasks. Furthermore, in the implementation of the learning process to achieve the learning objectives in accordance with the learning achievement, learning media that can motivate in learning, including: (1) interactive multimedia through interestingly designed animations that can improve learning, and not boring; (2) this interactive multimedia was designed based on parts and fragments into 
the smallest unit, so that it can easily understand the contents of the material presented; (3) interactive multimedia with communicative language and containing interesting illustrations will be effective, stimulating for independent learning; (4) this interactive multimedia can improve learning outcomes, can easily check the success of learning independently; and (5) this interactive multimedia in each section / fragment there was reinforcement, can improve learning outcomes in the ISD subject. This supported by research results that the use of computer-based interactive media more effective in improving student knowledge and understanding compared to using conventional media in the eyes of ISD with HOTS. And also the results showed that the average ISD learning outcomes with HOTS students who had positive innovative attitudes were more positive than ISD learning outcomes with HOTS students who had negative innovative attitudes. The implementation of learning with the MPMI4C-HOTS learning model in ISD using of educational technology which can be summarized as follows: (1) the ability of lecturers to refer only to textbooks, with this interactive multimedia-based learning model requires the lecturers to master more developing ICT-based knowledge, abilities increasing, because the source of knowledge that needs to be known was unlimited; (2) internet access a sustainability requirement from the MPMI4CHOTS learning model with the principles of learning technology. With the application of the MPMI4C- HOTS learning model with the principles of learning technology, it was increasingly maximizing the available facilities for the learning process and improving the quality of student learning. (3) has the opportunity to be further developed. According to Rusman, et al (2011), the advantages of computer-based learning are the application of the principles of complete learning or mastery learning. In the implementation of computer-based learning all students must be able to complete all learning experiences that are packaged in a computer-based learning program, whether it was understanding material and the task of doing tests or evaluations that must be completed correctly. If the student was wrong in doing the exercise questions, then the computer will give feedback, that the answer was wrong, so the student must return to the description of the material that has not been understood, after which the student can return to the practice question to do it correctly. Thus, students who have positive innovative abilities in the ability of ISD will quickly finish in studying the content/material of ISD lessons programmed in computer-based learning. But those who have negative innovative attitudes will have difficulty working on or understanding the content. Students who have high critical thinking skills have tendency to easily adapt to new knowledge, they prefer to learn face to face with challenging knowledge. This direct interaction will facilitate and accelerate the response to what they are doing. The results showed that those with high critical thinking abilities and taught with the MPMI4CHOTS learning model turned out that ISD mastery in education was higher than those using direct learning models without 4C and HOTS integration. This condition was appropriate, that those with high critical thinking skills are more likely to obtain information based on feedback and assimilate to previous experience. Critical thinking skills of students, are considered important to be developed at every level of education, to create and produce students who have good cognitive abilities in following the learning process and ability formation in HOTS (Haryani, 2012). In addition to the response speed, the number of exercises to solve problems will be more for those who use the MPMI4C-HOTS learning model. The more problems that are resolved will add to the experience as a provision to solve the next problem. Learning by using interactive multimedia on ISD means training problem-solving skills by using the stages of learning design correctly through the acceleration of ICT-based learning. To accept new concepts in ISD that are formed together with problem solving efforts. The courage of students with high critical thinking skills to try 
problem solving in various ways according to the rules of the system was a difficult step to take if they learn with direct learning strategies and without using interactive multimedia media. Synder and Synder (2008) asserted that teachers should instill critical thinking skills for students, students not only formed as recipients of information but must be information processors, this related to information in ISD. Because all systems in learning and education must first design and build knowledge about learning that was formed in the correct order and organized well by seeing and constructing students' thinking skills to realize the right and directed learning stages in all learning activities.

Other research results show that learning programs through critical thinking skills are very effective in improving students' academic abilities (Redhana and Liliasari, 2008). In another study also revealed that with good student thinking skills at the level of analysis, evaluation, and creation with HOTS achievements will increase the classical completeness of students beyond the minimum completeness criteria (Rahayu and Yonata, 2013). The ability to think critically high in the realm of HOTS was a problem-solving step in the learning process that was formed based on the level of competance skills, new concepts that they find themselves will add experience to solve the problem of ISD. According to Lambertus (2009), the development of students' critical thinking skills can be done through the application of student-centered learning, because they are given the freedom to build their own knowledge, discuss with friends, be free to submit opinions, be able to accept or reject the opinions of friends, and with the guidance of the teacher formulate conclusions

\section{Conclusion}

The conclusions in this study: (1) The average learning outcomes of students on ISD taught using the MPMI4C-HOTS learning model was superior to using the expository learning model with HOTS; (2) The average learning outcomes of students in ISD who have high critical thinking skills are superior to those with low critical thinking abilities; (3) there are differences in student learning outcomes in ISD between classes that use MPMI4C-HOTS learning models with classes that use expository learning models with HOTS, (4) there are differences in ISD learning outcomes of students with high critical thinking skills with students who have the ability low critical thinking. (5) there was interaction between the use of MPMI4C-HOTS learning model with the ability to think critically about ISD learning outcomes. 


\section{References}

[1] Azhar, A.: Media Pembelajaran, PT. Raja Grafindo Persada. Jakarta. (2011)

[2] Brookhart, S. M.: How to assess higher-order thinking skills in your classroom. ASCD. Alexandria, Virginia USA (2010)

[3] Conklin, W.: Higher-order thinking skills to develop21st century learners. Shell Educational Publishing, Inc. Huntington Beach.(2012)

[4] Ferawati.: Model Pembelajaran Multimedia Interaktif untuk Meningkatkan Penguasaan Konsep dan Keterampilan Generik Sains Guru Fisika pada Topik Fluida Dinamis. Proseding Penelitian Bidang Ilmu Eksakta, pp. 1-10. (2011)

[5] Gunawan, dkk.: Penggunaan Multimedia Interaktif dalam Pembelajaran Fisika dan Implikasinya pada Penguasaan Konsep Mahasiswa. Jurnal Pijar MIPA, Vol. IX No.1, pp. 15 - 19. (2014)

[6] Haryani, D.: Membentuk Siswa Berpikir Kritis Melalui Pembelajaran Matematik, Prosiding Jurusan Pendidikan Matematika FMIPA UNY. Yogyakarta (2012)

[7] Johnson, E.B.: Contextual Teaching \& Learning, Menjadikan Kegiatan Belajar-Mengajar Mengasyikkan dan Bermakna (diterjemahkan oleh Ibnu Setiawan), Penerbit MLC, Bandung.(2007)

[8] Kadir, A dan Triwahyuni.: Teknologi Informasi. Kanisius. Yogyakarta (2003)

[9] Kariadinata, R.: Kemampuan Visualisasi Geometri Spasial Siswa Madrasah Aliyah Negeri (MAN) Kelas X Melalui Software Pembelajaran Mandiri. Jurnal Pendidikan Fisika. Volume I, No. 2, pp. 1-13 (2010)

[10] Lambertus.: Pentingnya Melatih Keterampilan Berpikir Kritis dalam Pembelajaran Matematika di SD. Forum Pendidikan, 28(3), pp. 136-142.(2009)

[11] Liao, Y.K., 1992. Effects of Computerassisted Intruction on Cognitive Outcomes: A Meta Analysis. Journal of Research on Computing in Education, p.24 (1992)

[12] Nandi.:. Penggunaan Multimedia Interaktif Dalam Pembelajaran Di Persekolahan. Jurnal "GEA" Jurusan Pendidikan Geogarafi Vol.6, No.1, April (2006)

[13] Rahayu, T. and Yonata, B.:. Kemampuan Kognitif Siswa Kelas XI IPA 1 SMA Negeri 18 Surabaya pada Tingkat Analisis, Evaluasi, dan Kreasi pada materi Titrasi Asam Basa dengan Penerapan Model Pembelajaran Inkuiri. (2013)

[14] Redhana, I.W. and Liliasari, 2008. Program Pembelajaran Keterampilan Berpikir Kritis pada Topik Laju Reaksi untuk Siswa SMA, Forum Pendidikan. 27(2), pp. 103-112 (2008)

[15] Resnick, L. B.: Education and learning tothink.National Academy Press. Washington, D.C (1987)

[16] Rusman.: Model-model Pembelajaran: Mengembangkan Profesionalisme Guru. PT. Rajawali Pers. Jakarta. (2011)

[17] Rusman, dkk., 2011. Pembelajaran Berbasis Teknologi Informasi dan Komunikasi: Mengembangkan Profesionalisme Guru. PT Raja Grafindo Persada. Jakarta.(2011)

[18] Sa'ud .U. S.: Inovasi Pendidikan. Alfabeta. Bandung(2011)

[19] Seel, \& Richey.: Instructional Technology: The Definition and Domains of The Field. Association for Educationnal Commnications and Technology. Washington, DC (1994)

[20] Sriyanti, I.: M-Learning: Alternatif Media Pembelajaran di LPTK. Makalah Seminar Nasional Pendidikan.http://eprints.unsri.ac. id/2223/1/M._leaning.Sutopo, H,. 2008. Pengembangan Bahan Ajar Berbasis Multimedia. Tersedia http://www.topazart.info/teks_teaching/mat/flash/tutorialBahanAja rMultimedia.Pdf(2012)

[21] Suyanto, M.: Multimedia Alat untuk Meningkatkan Keunggulan Bersaing. Andi. Yogyakarta (2003)

[22] Synder, L. G. and Synder M.J.: Teaching Critical Thinking and Problem Solving Skill, The Delta Pi Epilson. 1(2), pp. 90-99 (2008)

[23] Thomas, A., G. Thorne, and Small, B.: High Order Thinking - It's HOTS http://cdl.org/resource-library/pdf/feb00PTHOT.pdf, di akses Januari 2018. Vaughan, T., 2011. Multimedia: Making It Work, McGraw-Hill. New York. 8th Edition (2000) 